\title{
Microwave-Assisted Grafting Polymerization Modification of Nylon 6 Capillary-Channeled Polymer Fibers for Enhanced Weak Cation Exchange Protein Separations
}

Liuwei Jiang ${ }^{1}$ and R. Kenneth Marcus* 


\section{ABSTRACT}

A weak cation exchange liquid chromatography stationary phase (nylon- $\mathrm{COOH}$ )

was prepared by grafting polyacrylic acid on to native nylon 6 capillary-channeled

polymer (C-CP) fibers via a microwave-assisted radical polymerization. To the best of

5 our knowledge, this is the first study of applying microwave-assisted grafting

6 polymerization to affect nylon material for protein separation. The C-CP fiber surfaces

7 were characterized by attenuated total reflection (ATR) infrared spectroscopy and

8 scanning electron microscope (SEM). The anticipated carbonyl peak at $1722.9 \mathrm{~cm}^{-1}$ was

9 found on the nylon- $\mathrm{COOH}$ fibers, but was not found on the native fiber, indicating the 10 presence of the polyacrylic acid on nylon fibers after grafting. The nylon-COOH phase 11 showed a $\sim 12 \mathrm{X}$ increase in lysozyme dynamic binding capacity $\left(\sim 12 \mathrm{mg} \mathrm{mL}^{-1}\right)$ when 12 compared to the native fiber phase $\left(\sim 1 \mathrm{mg} \mathrm{mL}^{-1}\right)$. The loading capacity of the nylon$13 \mathrm{COOH}$ phase is nearly independent of the lysozyme loading concentration $(0.05-1 \mathrm{mg}$ $\left.14 \mathrm{~mL}^{-1}\right)$ and the mobile phase linear velocity $\left(7.3-73 \mathrm{~mm} \mathrm{~s}^{-1}\right)$. The reproducibility of the 15 lysozyme recovery from the nylon- $\mathrm{COOH}(\mathrm{RSD}=0.3 \%, \mathrm{n}=10)$ and the batch-to-batch 16 variability in the functionalization $(R S D=3 \%, n=5)$ were also investigated, revealing 17 very high levels of consistency. Fast baseline separations of myoglobin, $\alpha-$ 18 chymotrypsinogen $A$, cytochrome $\mathrm{c}$ and lysozyme were achieved using the nylon$19 \mathrm{COOH}$ column. It was found that a $5 \mathrm{X}$ increase in the mobile phase linear velocity (7.320 to-36.5 $\mathrm{mm} \mathrm{s}^{-1}$ ) had little effect on the separation resolution. The microwave-assisted 21 grafting polymerization has great potential as a generalized surface modification 22 methodology across the applications of C-CP fibers. 
1 Keywords: Capillary-channeled polymer, fiber, surface modification, microwave-

2 assisted polymerization, ion exchange, chromatography 


\section{Introduction}

In recent years, macromolecular therapeutics have played increasingly important

3 roles in the pharmaceutical industry $[1,2]$. Protein-based drugs are the most common of

4 these macromolecular drugs. The manufacture of protein therapeutics involves two

5 major operations, upstream processing (i.e., production via cell culturing/fermentation)

6 and downstream processing (i.e., purification/recovery). Upstream processing has been

7 largely improved over the last two decades [3, 4], while the downstream processing

8 continues to be the rate limiting step in protein drug production $[3,5,6]$.

9 Chromatographic separation is the bottle-neck of the downstream processing due to its 10 high costs and time consumption. Thus there is a continuous interest in the 11 development of stationary phases that can provide high-throughput, cost-effective 12 protein separations [7, 8].

Traditional liquid chromatography (LC) stationary phases are composed of highly 14 porous, micro-sphere packed-bed support phases. While the majority of supports are 15 silica-based, polymeric materials find application due to their chemical robustness [9].

16 Currently, use of sub-2 $\mu \mathrm{m}$ diameter silica supports dominates the realm of "small 17 molecule" separations [10, 11]. However, the application of such supports in protein 18 separations suffers from the slow solute diffusion into and out the pores, limitations of 19 flow rate and backpressure, and the pore clogging due to the complexity of the 20 production mixtures. To this end, there has been a resurgence of interest in the use 21 superficially porous silica support phases [12, 13]. Additionally, alternative support 22 phases, such as monoliths, membranes and fibers, have been developed for protein 23 separations [14-19]. A recent review discussed the advantage of the using fiber based 
1 stationary phase for preparative-scale protein separations. The preparation of

2 preparative monolithic stationary phases remains challenging due to the low-

3 homogeneity of in situ polymerization, while fiber based stationary phases may be

4 prepared outside of the column and packed into large columns [19]. Capillary-

5 channeled polymer (C-CP) fibers have been under study in this laboratory towards

6 applications in protein analytics and downstream processing [20-25]. The C-CP fiber-

7 packed bed presents a number of physical advantages over porous microsphere-

8 packed beds. The combination of a virtually non-porous fiber structure and high

9 permeability allows for analytical separations that can be run at high mobile phase linear

10 velocity $\left(100 \mathrm{~mm} \mathrm{~s}^{-1}\right)$ while maintaining low column backpressure $(<2000 \mathrm{psi})[26,27]$.

11 Short inter-fiber diffusion distances combine with the lack of porosity to minimize the

12 mass transfer resistance of proteins, allowing for very high processing throughput [28].

13 C-CP fibers are melt-extruded from commodity polymers such as polyamide (nylon 6),

14 polyester (PET) and polypropylene (PP). The low-cost of the C-CP fibers makes them

15 an attractive candidate in terms of implementation on the industrial-scale.

16 The different surface chemistries provided by the base C-CP fiber phases allows

17 for protein separations under reversed-phase (RP), hydrophobic interaction (HIC), and

18 ion-exchange (IEX) modes [21, 22, 29, 30]. Just as in the case of poly(styrene-

19 divinylbenzene) (PS-DVB) bead phases [9, 31, 32], there exists a rich tool box of

20 surface modification chemistries to effect greater chromatographic efficiency and

21 selectivity. Several surface modification strategies have been pursued on C-CP fibers to

22 affect greater efficiency/selectivity, with the caveat that retention of the basic

23 hydrodynamic properties was essential. For example, simple amination of the PET 
1 surface has allowed creation of a biotinylated surface for affinity separations [33] and

2 the creation of polymeric polyethyleneimine (PEI) phases for weak anion exchange

3 protein separations [34, 35]. A new class of surface functionalizing agent, ligand

4 tethered lipids (LTL), was developed for surface functionalization of PP C-CP fibers for

5 protein extractions and separations [36, 37]. These modification strategies introduce

6 different types of surface chemistries on C-CP fiber phase and expand the potential

7 applications of C-CP fiber phase.

8 In terms of the ability to mitigate any decomposition/deactivation of product

9 proteins, ion exchange-based separations are extremely attractive [8]. Unfortunately,

10 hydrophobic interactions between proteins and no-polar support phases lead to

11 separations that are actually mixed-mode in nature [9, 38, 39]. Hydrophobic

12 interactions can cause proteins to de-nature during separations, lead to low protein

13 recoveries, and peak tailing in chromatograms. Therefore, hydrophilic supports such as

14 acrylates are common in IEX protein separations [40]. Among the types of C-CP fiber

15 materials, nylon 6 is the most hydrophillic. Based on the acid/base character depicted

16 below for the natural carboxylic acid and primary amine end groups,

† $\mathrm{H}_{3} \mathrm{~N}$-nylon-COOH $\stackrel{\mathrm{OH}-}{\rightleftarrows}$ $\mathrm{pH}<3$ $\mathrm{H}_{3} \mathrm{~N}$-nylon-COO $\underset{\mathrm{OH}-}{\stackrel{(}{\rightleftarrows}} \mathrm{H}_{2} \mathrm{~N}$-nylon-COO
3-8 native nylon 6 C-CP fibers have been used in IEX protein separations [30, 41].

However, the low density of these ion-exchange ligands limits the performance of the material in protein separations [35]. Thus additional surface modifications on the native nylon $6 \mathrm{C}$-CP fibers are needed to improve the chromatography properties of this phase. 
Presented here is a proof-of-concept in the modification of nylon 6 C-CP fibers

2

3

4

5

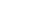

7

8

8

used in weak cation exchange (WCX) protein separations, without sacrificing the nature

of the hydrophilic surface or the column hydrodynamics. As-extruded fibers were

functionalized via a microwave-assisted grafting polymerization. Acrylic acid was

polymerized and grafted onto the native nylon 6 C-CP fibers as the functional ligands.

The modified fiber (nylon- $\mathrm{COOH}$ ) packed columns exhibit significantly-increased protein

7 dynamic binding capacity. Protein recoveries and the reproducibility of the modification

were investigated on the nylon- $\mathrm{COOH}$ fibers. Finally, fast protein separations were demonstrated on the nylon- $\mathrm{COOH}$ fiber phase. To the best of our knowledge, this is the first study of applying microwave-assisted grafting polymerization to affect nylon material for protein separation. The microwave-assisted modification is a versatile method to introduce various functional ligands onto the nylon C-CP fiber phase, thus it greatly expands and improves the application of nylon 6 C-CP fiber phase for analytical and, eventually preparative, protein separations.

\section{Materials and methods}

\subsection{Chemicals and instrumentation}

Unless otherwise specified, chemicals were purchased from commercially available sources and used without further purification. Nylon 6 C-CP fibers were obtained from the Material Science and Engineering department, Clemson University.

The denier per filament (DPF) of the fibers employed here is $2.67 \mathrm{~g}$ per $9000 \mathrm{~m}$, with each fiber having a cross-sectional perimeter of $208 \mu \mathrm{m}$. Acrylic acid $(99.5 \%)$ and potassium persulfate (KPS) (99\%) were purchased from Alfa Aesar (Haverhill, MA). Activated alumina powder was purchased from Polysciences, Inc. (Warrington, PA). All 
1 HPLC solvents were purchased from EMD (Billerica, MA). All other chemicals and all

2 proteins were purchased from Sigma-Aldrich (St. Louis, MO). Deionized water $\left(\mathrm{DI}-\mathrm{H}_{2} \mathrm{O}\right)$

3 was secured from a Milli-Q water system. The protein loading/elution characterization

4 and chromatographic protein separations were performed on a Dionex Ultimate 3000

5 HPLC system, LPG-3400SD Quaternary pump, and MWD-3000 UV-vis absorbance

6 detector (Thermo Fisher Scientific Inc., Sunnyvale, CA). A Rheodyne model 8125 low

7 dispersion injector with a $5 \mu \mathrm{L}$ injection loop was used for protein sample injections. The

8 microwave-assisted polymerizations were performed in a Sunbeam SBM7700W

9 microwave oven, without any modifications of the commercial unit.

\subsection{Microwave-assisted nylon C-CP fiber surface modification}

The surface grafting polymerization method was modified from an earlierreported method [42]. All DI- $\mathrm{H}_{2} \mathrm{O}$ used in the modification reactions was purged with nitrogen for $30 \mathrm{~min}$ to remove oxygen prior to use. The acrylic acid was filtered through an activated alumina bed to remove remnant stabilizing agents before use. The modification solution was prepared by dissolving acrylic acid $(2.0 \mathrm{~mL}, 29 \mathrm{mmol})$ and potassium persulfate $(100 \mathrm{mg}, 0.37 \mathrm{mmol})$ in $20 \mathrm{~mL} \mathrm{DI}-\mathrm{H}_{2} \mathrm{O}$. The native nylon $6 \mathrm{C}-\mathrm{CP}$ fibers were removed from the fiber spool and placed on a dying fork. For each modification reaction, 720 fibers of $\sim 35 \mathrm{~cm}$ length were used. The fibers were rinsed with excess amounts of $\mathrm{DI}-\mathrm{H}_{2} \mathrm{O}$, methanol, and then $\mathrm{DI}-\mathrm{H}_{2} \mathrm{O}$ again, to remove any chemical residues left from the fiber extrusion process. The fibers were immersed into the modification solution in a $50 \mathrm{~mL}$ beaker and the beaker placed in the microwave oven. Due to the small scale of the reaction, another beaker containing $30 \mathrm{~mL}$ water was also placed in the microwave oven as a heat sink for better control and 
1 reproducibility of the experiments. The microwave reaction was run at $100 \mathrm{~W}$ for $10 \mathrm{~min}$.

2 After reaction, the fibers were removed from the beaker immediately and washed with

3 excess amounts of $\mathrm{DI}-\mathrm{H}_{2} \mathrm{O}$ until no homopolymer parciptates were visible on the fibers.

4 A control experiment was run with the fibers submerged in neat $\mathrm{DI}-\mathrm{H}_{2} \mathrm{O}$ instead of in the

5 modification solution to assess any thermal or microwave-induced decomposition.

\section{$6 \quad 2.3 \quad$ Preparation of the C-CP fiber columns}

7 The C-CP fiber columns were packed following the previously-reported

8 procedure [27]. In this study, 720 native or modified nylon 6 fibers were pulled through 9 polyether ether ketone tubing (PEEK, $0.762 \mathrm{~mm}$ i.d., IDEX Health \& Science LLC, Oak 10 Harbor, WA). After packing, columns were mounted on the HPLC system and washed 11 with $\mathrm{DI}-\mathrm{H}_{2} \mathrm{O}$ at $0.2 \mathrm{~mL} \mathrm{~min}{ }^{-1}$ for $12 \mathrm{~h}$ to remove any non-covalently bound chemicals 12 (initiators, homopolymers) from the fibers. Once cleaned, the fiber-packed columns 13 could be cut to appropriate length ( $20 \mathrm{~cm}$, in this study) and stored in ambient 14 conditions.

\subsection{Characterization of the modified nylon 6 C-CP fibers}

Scanning electron microscope (SEM) images were taken at the Clemson

University Electron Microscopy Laboratory, using a Hitachi SU6600 system operating in the variable pressure mode, with a $20 \mathrm{kV}$ accelerating voltage. Attenuated total reflection-Fourier transform infrared spectroscopy (ATR-FTIR) was performed on a Thermo-Nicolet Magna 550 FITR in the Analytical Testing Lab of the Material Science \& Engineering Department, Clemson University. The ligand densities of native and 23 fibers were washed in $100 \mathrm{mM} \mathrm{HCl}$ solution for $1 \mathrm{~min}$, and then large amounts of $\mathrm{DI}$ - 
$1 \mathrm{H}_{2} \mathrm{O}$ to remove residual $\mathrm{HCl}$ from the fibers. The fibers were then washed with acetone

2 to remove water, and dried under mild mechanical vacuum for 20 hours at room

3 temperature to remove residual solvent. The dried fibers, were weighed, placed in DI-

$4 \quad \mathrm{H}_{2} \mathrm{O}$, and were titrated with standardized $0.1142 \mathrm{M} \mathrm{NaOH}$ solution and phenolphthalein

5 used as the end-point indicator.

\section{$6 \quad 2.5 \quad$ Liquid chromatography}

7 All experiments were performed on a Dionex Ultimate 3000 HPLC system. The

8 dynamic loading capacity (DLC) of the columns (column length: $200 \mathrm{~mm}$, i.d.: $0.762 \mathrm{~mm}$ )

9 was determined through breakthrough (frontal) analysis as described previously [23], 10 using lysozyme as the test protein. After the column was cleaned and equilibrated with $1120 \mathrm{mM}$ phosphate buffer $(\mathrm{pH}=6.5$, designated as buffer $\mathrm{A})$, lysozyme at the chosen 12 concentration in the buffer was introduced to the column. UV absorbance at $280 \mathrm{~nm}$ 13 was monitored as a means of detecting breakthrough and quantifying the amount of 14 protein retained on-column. When the UV absorbance of the eluting solution reached a 15 plateau, indicating column saturation, buffer A was then applied on the column to 16 remove non-bound protein. When the absorbance returned to the original baseline, 17 buffer $B(1.0 \mathrm{M} \mathrm{NaCl}$ in buffer $\mathrm{A})$ was introduced to the column to affect protein elution.

18 The amount of lysozyme retained was determined by integration of the breakthrough 19 curve (equal area method).[43] A blank experiment was performed using an empty 20 PEEK tubing to determine the system hold-up volume/time. The DLC at $10 \%$ 21 breakthrough was calculated at the point that the absorbance of the eluting solution 22 reached $10 \%$ of its maximum absorbance (plateau). While there was very little 23 evidence that it was necessary, columns were cleaned/regenerated between 
1 experiments by passing a $100 \mathrm{mM} \mathrm{NaOH}$ solution for $10 \mathrm{~min}$ to remove residual,

2 strongly-bound proteins.

The analytical quality of the protein separations was determined using gradient

4 separations (from $100 \%$ buffer A to $50 \%$ buffer B) of a four-protein mixture. For each

5 separation experiment, $5 \mu \mathrm{L}$ of the protein mixture containing myoglobin, $\alpha-$

6 chymotrypsinogen $A$, cytochrome $C$ and lysozyme $\left(0.25 \mathrm{mg} \mathrm{mL}^{-1}\right.$ each) was injected

7 and the chromatogram was recorded at $216 \mathrm{~nm}$. The gradient baseline absorbance was

8 obtained by running the gradient with no protein injected. The absorbance baseline was

9 subtracted from protein separation chromatograms.

\section{Results and discussions}

\subsection{Microwave-assisted nylon surface polymerization modification}

Different methods have been reported in the literature for the modification nylon

materials. Some of the modification methods target activation of the amide groups [44, 45], unfortunately resulting in cleavage of the amide bond and causing inevitable physical damage to the nylon bulk structure. Such a decrease of mechanical strength to the $\mathrm{C}$-CP fibers would result in breakage in the column packing process. The other principal type of modification introduces the target species onto the nylon surface via polymerization of a monomer containing the desired functional groups [42, 46]. Radical polymerization reactions are usually induced by UV light, conventional heating, plasma or microwave energy $[42,46,47]$. UV light treatment is a straight forward, easily controlled approach, but is not applicable on large quantities of material or on materials that have non-uniform shapes, such as C-CP fibers. The conventional heating method requires mixing or stirring of the materials in the reactive solution. Such an approach on 
1 C-CP fibers would results in folding and twisting, greatly reducing the homogeneity of

2 the fiber column packing if not prohibiting it all together. Plasma beam treatments are

3 difficult to impart on non-uniform surfaces and cause severe degradation of the

4 polymers and decreased their mechanical properties due to oxidative damage $[46,48]$.

5 Finally, microwave-irradiation is a well-established technique and its application to

6 surface polymerization has been widely investigated [49-52]. Microwaves consist of

7 electromagnetic radiation that has frequencies of $300 \mathrm{MHz}$ to $300 \mathrm{GHz}$, corresponding

8 to wavelengths of $\sim 1 \mathrm{~m}$ to $1 \mathrm{~mm}$, which can penetrate through many materials. The

9 majority of microwave sources that are used for industrial and domestic purposes

10 operate at a frequency of $2.45 \mathrm{GHz}$, corresponding to the wavelength of $\sim 12 \mathrm{~cm}$. In

11 comparison to conventional heating methods, microwave irradiation offers many

12 advantages including non-contact heating, rapid heating, high levels of temperature

13 homogeneity, selective heating (some materials absorb more microwave radiation than

14 others) and low energy cost. Non-thermal "microwave effects" that enhance the

15 reactions may exist, but the exact mechanisms are still under discussion [53-55].

In this study, native nylon $6 \mathrm{C}$-CP fiber surfaces were functionalized by radical grafting polymerization as depicted below, with KPS used as the radical initiator. The mechanisms of KPS decomposition and KPS-initiated grafting polymerization have been discussed $[42,56]$. 
1 The power of the domestic microwave oven used for the modification reaction was set

2 at $100 \mathrm{~W}$, the lowest power option on that particular unit. The scale of the reaction (20

$3 \mathrm{~mL}$ ) in this study is quite small in comparison to the heating capacity of the domestic

4 microwave oven. As such, an additional beaker containing $30 \mathrm{~mL}$ of water was placed

5 in the microwave oven as a "heat sink". Without the "heat sink", the reaction mixture

6 heats too quickly. In such cases, large amounts of air bubbles and homopolymer

7 precipitants are formed after 5 min of microwave reaction and the modifications lack

8 reproducibility. With the heat sink, the reaction is run for 10 min with greatly improved

9 reproducibility. It is believed that using a more controllable microwave reactor, such as

10 employed in the organic synthesis community would improve the modifications.

11 However, the less expensive domestic microwave oven is sufficient for the proof-of-

12 concept study of using the nylon-COOH C-CP fiber phase for protein separations.

The acrylic acid-functionalized nylon fibers (nylon- $\mathrm{COOH}$ ) were characterized using ATR-FTIR and compared to the native nylon 6 starting material (Fig. 1). Both spectra show virtually identical peaks from the nylon bulk structure: $3294 \mathrm{~cm}^{-1}$ (amide A, $\mathrm{N}-\mathrm{H}$ stretch), $3062 \mathrm{~cm}^{-1}$ (NH stretch), $2931 \mathrm{~cm}^{-1}$ and $2862 \mathrm{~cm}^{-1}$ (anti-symmetric and symmetric $-\mathrm{CH}_{2}$ - stretch), $1636 \mathrm{~cm}^{-1}$ (amide I), $1545 \mathrm{~cm}^{-1}$ (amide II), $1457 \mathrm{~cm}^{-1}\left(\mathrm{CH}_{2}\right.$ scissors), $1369 \mathrm{~cm}^{-1}$ (amide III and $\mathrm{CH}_{2}$ wagging), $1260 \mathrm{~cm}^{-1}$ ( $\mathrm{NH}$ bending and $\mathrm{C}-\mathrm{H}$ stretch), $1197 \mathrm{~cm}^{-1}$ ( $\mathrm{CH}_{2}$ twist-wagging), $1168 \mathrm{~cm}^{-1}$ (CO-NH skeletal motion), $685 \mathrm{~cm}^{-1}$ (out of plane bends of $\mathrm{NH}$ ), $579 \mathrm{~cm}^{-1}$ (out of plane bends of $\mathrm{C}=\mathrm{O}$ ). The results are consistent with reported values [57]. The peak at $1722.9 \mathrm{~cm}^{-1}(\mathrm{C}=\mathrm{O}$ stretch $)$ in the Nylon- $\mathrm{COOH}$ case is consistent with literature reported carbonyl $\mathrm{C}=\mathrm{O}$ stretch in poly acrylic acid [58], indicating the presence of those new groups on the nylon- $\mathrm{COOH}$ fiber 
1 surfaces, which were not apparent in the spectrum of the native nylon 6 . The fact that

2 the other spectral features are not changed reflects the fact that the polymer backbone

3 is not perturbed by the modification process.

As noted previously, the driving force for these efforts was the desire to attain

5 high densities of carboxylic acid WCX groups on the already-hydrophilic nylon 6 support.

6 Earlier efforts in assessing the end group densities on nylon 6 were based on the

7 classic ninhydrin reaction, which actually measures primary and secondary amine

8 densities, which should equate nominally with the carboxylic acid values as there are no

$9 \quad 2^{\circ}$ amines in the nylon system. Here, a simple acid/base neutralization titration has

10 been applied to specifically quantify the $-\mathrm{COOH}$ densities. Those determinations yield

11 values of $28 \pm 9 \mu \mathrm{mol} \mathrm{g} \mathrm{g}^{-1}$ of fiber for the native nylon 6 and $575 \pm 7 \mu \mathrm{mol} \mathrm{g} \mathrm{g}^{-1}$ for the

12 nylon- $\mathrm{COOH}$, an $20 \mathrm{X}$ increase following the microwave-enhanced grafting method.

13 The $-\mathrm{COOH}$ value here is a factor of $\sim 2.5 \mathrm{X}$ less than obtained for the same fiber using

14 the ninhydrin test, which is not out of line given the uncertainties of that method. In

15 comparison to other polymer-based WCX phases, density of the nylon-COOH is higher

16 than carboxylic acid functionalized poly(glycidyl methacrylate-co-ethylene

17 dimethacrylate) beads (-COOH density $\left.400 \mu \mathrm{mol} \mathrm{g}^{-1}\right)$ [59] and chloroacetic acid

18 modified polymeric monolith $\left(-\mathrm{COOH}\right.$ density $\left.351 \mu \mathrm{mol} \mathrm{g}{ }^{-1}\right)$ [60]. To better classify the

19 nylon-COOH ligand density versus other WCX phases, it is better to express that value

20 of $\sim 820 \pm 10 \mu \mathrm{mol} \mathrm{m}$, based on native fiber specific surface area of $\sim 0.7 \mathrm{~m}^{2} \mathrm{~g}^{-1}$. In

21 terms of a surface area basis, this is a very high density of surface ligand, in

22 comparison to a surface functionalized silica gel developed for protein separations,

23 having a carboxylic acid density of $0.568 \mu \mathrm{mol} \mathrm{m} \mathrm{m}^{-2}$ [61]. It must be emphasized that, 
1 based on the virtual non-porosity of the C-CP fibers, all of the surface ligand are

2 accessible, versus those that might lie within porous structures of other phases. While it

3 may be questioned, we have no direct evidence as to the primary "directionality" of the

4 polymerization process, normal to or laterally on the surface.

5 As stated previously, it is imperative that any modification process not lead to

6 sacrifices in the hydrodynamic efficiency of the C-CP fiber columns. SEM imaging of

7 the fibers provides some evidence of potential macroscopic changes as seen in Fig. 2.

8 The images of the column cross sections of the native nylon 6 and nylon- $\mathrm{COOH}$ (Figs.,

$92 a$ and $b$, respectively) suggest that the modified fibers are packed more tightly (i.e.,

10 their fiber diameters have increased), even though the number of the fibers is the same

11 in both columns (720 fibers). This point is more readily seen in the magnified views of

12 Figs. 2c and d. In the chromatography experiments, the back-pressure of using nylon-

$13 \mathrm{COOH}$ column is $\sim 2 \times$ higher than using native nylon column (though still comparatively

14 low). While not determined explicitly, this would suggest that the interstitial fraction of

15 the columns packed with nylon- $\mathrm{COOH}$ fibers has decreased from a value of $\varepsilon_{\mathrm{i}}=0.63$ to

$16 \sim 0.45$ [9]. One might question whether the increased thickness is simply the result of

17 swelling in the hot water, microwave modification step. In fact, micrographs of control

18 samples of the nylon 6, microwaved in $\mathrm{DI}-\mathrm{H}_{2} \mathrm{O}$ instead of the modification solution,

19 showed no difference in SEM images in comparison to the native fibers. Hence, the

20 increase in fiber thickness following modification appears to be due to the added

21 polyacrylic acid layer from the grafting polymerization. As a final assessment of

22 potential damage/change during the microwave modification process, side-on SEM

23 images (Figs. 2e and f) indicate no macro-damage to the fiber channel structures. 
1 These findings support the desired outcome that the grafting polymerization is a non-

2 destructive surface modification method.

\subsection{Dynamic loading capacity}

The DLC of the native and modified nylon $6 \mathrm{C}$-CP fiber phases were determined

5 by breakthrough experiments using lysozyme as the model protein. Preliminary

6 assessment of the throughput and yield characteristics of the C-CP fiber phases were

7 done with the same lysozyme/nylon 6 system [23]. Under buffer conditions of $\mathrm{pH} 6.5$,

8 the carboxylic acid on the native nylon (as the end groups) and nylon- $\mathrm{COOH}$ fiber

9 phase carry negative charges. Lysozyme has the isoelectric point of $\sim 11.3$ and so has

10 a net positive charge in the buffer, thus it interacts with the native and modified nylon

11 fiber phases via electrostatic interactions. Various concentrations $\left(0.05-1.0 \mathrm{mg} \mathrm{mL}^{-1}\right)$

12 of lysozyme solutions were loaded onto the fiber columns at a flow rate of $0.4 \mathrm{~mL} \mathrm{~min}^{-1}$

$13\left(\mathrm{U}_{0} \cong 29.2 \mathrm{~mm} \mathrm{~s}^{-1}\right)$. Increasing the ionic strength of the buffer $(1.0 \mathrm{M} \mathrm{NaCl})$ elutes the

14 lysozyme from the fiber phases following each loading. Representative breakthrough

15 curves (UV absorbance at $280 \mathrm{~nm}$ ) are shown in Fig. 3. Plotting on a time axis depicts

16 the expected temporal response; as the concentration is increased, breakthrough

17 occurs at shorter times/volumes. Frontal analysis of the breakthrough data in terms of

18 the absolute amounts of protein allows calculation of the dynamic binding capacities

19 presented in Table 1, in terms of the mass of lysozyme per unit fiber mass ( $\mathrm{mg} \mathrm{g}^{-1}$ ) and

20 bed volume $\left(\mathrm{mg} \mathrm{mL}^{-1}\right)$. The DLC of nylon fiber phase varies from about $0.4-1 \mathrm{mg} \mathrm{mL}^{-1}$

21 on the native nylon to about $10-12 \mathrm{mg} \mathrm{mL}^{-1}$ on the nylon-COOH. There is a good bit

22 of scatter in the native nylon 6 data as the absolute difference between the

23 breakthrough volumes in those cases is very close to the actual column breakthrough 
1 (hold-up) volume. On the other hand, the precision of replicate loadings is much better

2 for the nylon- $\mathrm{COOH}$ phase as the absolute values are much higher. There is a very

3 slight (positive) dependence on the binding capacity for the modified surfaces versus

4 the load concentrations, conforming to the upper-concentration regions of what would

5 be expected to be a Langmuir or Langmuir-linear isotherm [24, 34, 43]. Fitting of the

6 isotherm data results in a maximum dynamic binding capacity $\left(Q_{m}\right)$ of $12.4 \mathrm{mg} \mathrm{mL}^{-1}$ bed

7 volume, which is very comparable to WAX C-CP fiber phases [34]. It is easy to

8 conclude that the $12 \mathrm{X}$ increase in DLC is attributed to the added acrylic acid (-COOH)

9 ligands following modification.

11 natural questions as to potential perturbations of the loading/elution kinetics. One

12 useful metric towards this regard is the ratio between the $10 \%$ and $50 \%$ breakthrough

13 (BT) volumes obtained through frontal analysis. These values reflect the amount of

14 bound lysozyme at the point when the lysozyme concentration of the eluent reaches $10 \%$

15 and $50 \%$ of the maximum (solution) concentration. The ratio of the DLC at $10 \%$ to the

16 DLC at $50 \%$ reflects the sharpness of the breakthrough curve. In these lysozyme

17 loading experiments, the ratios on the nylon- $\mathrm{COOH}$ column range from $0.82-0.86$,

18 indicative of the high efficiency of mass transfer on the nylon- $\mathrm{COOH}$ phase. There is no

19 significant change in the $10 \% / 50 \%$ BT ratio across the protein feed concentration

20 changes, which would be expected in a diffusion-limited loading situation. This reflects

21 the convective-diffusion driven solute transport that takes place in the C-CP fiber beds

22 [28]. Overall, the protein DLC of a separation media at low protein feeding

23 concentrations (e.g., $0.05 \mathrm{mg} \mathrm{mL}^{-1}$ ) is especially important for industrial applications, 
1 since many of the desired proteins can be present at low concentrations in cell lysate

2 media. This high loading capacity is complemented by the efficient adsorption kinetics,

3 suggesting that the nylon- $\mathrm{COOH}$ phase holds great potential for use in large-scale

4 protein extraction and purification.

6 in the production of bio-therapeutics. The advantages of operating a separation under

7 conditions which affect high throughput $(\mathrm{T})$ and yield $(\mathrm{Y})$ are ultimately desirable, these

8 are some of the most outstanding attributes of C-CP fiber phases [23, 24]. Figure 4

9 presents representative lysozyme breakthrough curves on the nylon- $\mathrm{COOH}$ column at various flow rates/linear velocities. In this experiment, the lysozyme load concentration was kept at a constant value of $1 \mathrm{mg} \mathrm{mL}^{-1}$. The breakthrough curves are plotted on the basis of the load solution volume to better-reveal any kinetic limitations. As seen in the scale expansion, there is a very slight bias in the volume equating to the $50 \%$ load, with the slowest application yielding an $\sim 4 \%$ higher binding capacity than the highest velocity, though the latter occurred at a $10 \times$ higher velocity/shorter time scale. Thus, a vast improvement in $\mathrm{T}$ is observed. It is also interesting to note that the volume displacement at the $10 \%$ breakthrough between the different velocities and the $50 \%$ level are virtually the same, thus the mass transfer/adsorption kinetics are not sacrificed at the higher linear velocities. Only in the case of the highest linear velocity $\left(73 \mathrm{~mm} \mathrm{~s}^{-1}\right)$ does it appear that mass transfer limitations are occurring, as the slope of the total breakthrough curve begins to decrease. The negligible difference on DLC at various linear velocities indicates the low mass transfer resistance of the nylon- $\mathrm{COOH}$ phase at 
1 high flow rates, thus fast protein loading/elution can be realized to improve the

2 throughput of protein separations.

7 monolith $\left(6 \mathrm{mg} \mathrm{mL}^{-1}\right)$ [62] and methacrylic acid- polyethylene glycol diacrylate monolith

$8 \quad\left(0.065 \mathrm{mg} \mathrm{mL}^{-1}\right)$ [63]. The lysozyme loading capacity of nylon-COOH fiber is

9 comparable to $\mathrm{CIMac}^{\mathrm{TM}} \mathrm{CM}$ monolith $\left(9-11 \mathrm{mg} \mathrm{mL}^{-1}\right.$, http://www.biaseparations.com)

10 but lower than ProSwift WCX-1S monolith (23 mg mL ${ }^{-1}$, www.thermofisher.com) and

11 Sartobind $\circledast \mathrm{C}$ membrane $\left(21 \mathrm{mg} \mathrm{mL}^{-1}\right.$, www.sartorius.com). However, it needs to be

12 pointed out that the linear velocities of the protein feed on nylon- $\mathrm{COOH}$ fiber with 200

$13 \mathrm{~mm}$ bed height is significantly higher than the flow linear velocity allowed on other

14 phases even with much shorter bed height $(4-70 \mathrm{~mm})$. Nylon- $\mathrm{COOH}$ fiber phase is

15 believed real advantages as an IEX phase capable of high throughput protein 16 separations.

\subsection{Consistency of the protein loading and elution}

The ability to consistently recycle columns after saturation is a key attribute in terms of practical column lifetime. In many instances, some form of clean-in-place (CIP) step is required, both to remove undesirable contaminants such as host cell proteins (in downstream processing) as well as "unrecovered" target proteins in analytical separations. More so than in analytical-scale separations, the ability to maintain consistent, high efficiency is challenging in preparative-scale applications where 
1 complete column saturation may occur. This is of course the case in the dynamic

2 loading studies employed here, and so an evaluation of column stability/reproducibility

3 was performed. After an initial cleaning using a $100 \mathrm{mM} \mathrm{NaOH}$ solution, 10 complete

4 load/elute cycles were executed without any CIP performed in between. The

5 subsequent load/elute transients are presented in Fig. 5, stacked from first-to-last from

6 the bottom-to-top. As seen in each case, the nylon- $\mathrm{COOH}$ fiber bed is saturated. The

7 consistency shown here is quite impressive in terms of both the load and elution steps,

8 with the load masses (via breakthrough volumes) differing by only $0.2 \% R S D(n=10)$

9 and the recoveries (via the integrated areas under the curve) by only $0.3 \% R S D(n=10)$.

10 As an extension, though not needed here, the same experiment was repeated 6

11 additional times, with $10 \mathrm{~min} .100 \mathrm{mM} \mathrm{NaOH}$ CIP exposures between each. Here again,

12 there was no loss in binding capacity or recovery efficiency. This bares testament to the

13 chemical robustness of the acrylic acid overlayer and the physical robustness of the

14 base nylon fibers towards use for downstream processing applications.

15

\subsection{Batch-to-batch reproducibility of the modification process}

It is a natural concern, due to the fact that the microwave modification reactions were not well controlled, that the batch-to-batch reproducibility would be suspect when using a simple domestic microwave oven. Different from commercial units designed for organic synthesis, the operational aspects of these units are not held to high rigor or precise control. To test the reproducibility of the polymerization process, columns were made once a week for 5 consecutive weeks. Shown in Fig. 6 are the load/elute transients for those 5 columns $\left(1.0 \mathrm{mg} \mathrm{mL}^{-1}\right.$ lysozyme loading concentration at $0.5 \mathrm{~mL}$ $\min ^{-1}$ ), directly overlaid to emphasize the quality of the processing. The consistency 
1 shown here is very impressive in terms of both the load and elution steps, with the

2 differences in load masses differing by only $3 \% \operatorname{RSD}(n=5)$ and the recoveries by only

$32 \% \operatorname{RSD}(n=5)$. The overall performance of these columns is equivalent, though there

4 are very slight differences seen in the transition regions of the breakthrough curves as

5 seen in the insert of the figure. Since all of the columns were manually assembled

6 following the microwave modifications, the variation due to the column packing is likely

7 a contributing factor in the shapes of breakthrough curves. It is believed that these

8 variations can be overcome by optimizing the column packing method and using better,

9 controllable microwave reactors.

\subsection{Rapid protein separation}

While the load/elute studies readily demonstrate the enhanced loading capacity of the nylon- $\mathrm{COOH}$ phase versus native nylon 6 , it would be equally desirable to have that phase be viable for analytical protein separations. The primary metrics here are the capacity to adequately separate the mixture components (an enthalpic quality) while also providing very high throughput (an entropic quality). Protein separations were evaluated at linear velocities of 7.3 and $36.5 \mathrm{~mm} \mathrm{~s}^{-1}$ for a four-protein (myoglobin, $\alpha$ chymotrypsinogen $A$, cytochrome $C$ and lysozyme) mixture using a more or less generic $\mathrm{NaCl}$ gradient. The chromatograms of the separations are showed in Fig. 7. The top set of chromatograms (Fig. 7a) reflects the protein separations on the native nylon 6 fiber phase. The native nylon has carboxylic acid end groups, however their low density leads to poor retention and broad elution peaks.[35] The cytochrome C component (2) is split into two peaks, the first peak co-eluted with the non-retained myoglobin (1) and the second co-eluting with chymotrypsinogen-A (3) as confirmed by single component 
1 injections. Meanwhile, the lysozyme peak (4) exhibits severe tailing and poor recovery.

2 Use of the lower linear velocity (dashed line) provides little significant improvement.

3 The same gradient separations were performed on the nylon- $\mathrm{COOH}$ column, as in the

4 case of the nylon 6 . The four proteins were well separated on the nylon- $\mathrm{COOH}$ column

5 (Fig. 7b), with the hydrophilic myoglobin still remaining un-retained. The other proteins

6 show well-behaved responses, with high recoveries. Tuning the gradient results in

7 baseline separation of four proteins (Fig. 7c). The increase on the mobile phase linear

8 velocity $(5 \mathrm{X})$ did not significantly impair the separation in both fig $7 \mathrm{~b}$ and $7 \mathrm{c}$. Consistent

9 with previous protein separations on C-CP fiber phases [21, 22], increases in linear

10 velocity do not diminish the resolution, with a tendency for the proteins to elute at a

11 slightly lower solvent strength [21]. In these instances, the apparent loss of recovery

12 (based on lower absorbance signals) is due to solute dilution per unit time and some

13 time constant bias in the optical detection system. In the best case of the high velocity

14 separation depicted in Fig. 7c, the protein processing rate is $1 \mathrm{mg}$ protein on a $0.36 \mathrm{~mL}$

15 bed in a time of less than 6 mins. Indeed, this throughput is limited primarily from the

16 (needless) $1.5 \mathrm{~min}$ solvent hold time before the initiation of the gradient. Clearly the

17 nylon- $\mathrm{COOH}$ fiber phase provides a much-improved platform for high-throughput WCX 18 protein separations.

\section{4. Conclusions}

20 This proof-of-concept study demonstrates the feasibility and practical advantages

21 of the nylon- $\mathrm{COOH} \mathrm{C}-\mathrm{CP}$ fiber phase for protein separations. The native nylon $\mathrm{C}-\mathrm{CP}$

22 fibers were functionalized with acrylic acid via a microwave-assisted grafting

23 polymerization. Acid/base titrations reveal increased ligand density (- $\mathrm{COOH}, 575 \pm 7$ 
2 packed column showed a $12 \mathrm{X}$ increase in protein dynamic binding capacity versus

3 native nylon fibers, with values that are nearly independent to the mobile phase linear

4 velocity. Excellent recovery of lysozyme was demonstrated on the nylon- $\mathrm{COOH}$ fiber

5 phase under ion-exchange elution conditions. The intra- and inter-batch reproducibility

6 was found to be $0.3 \%$ and $3 \%$. Fast protein separations (6 min gradients employed

7 here, but much faster are reasonable ${ }^{22}$ ) were demonstrated on the nylon- $\mathrm{COOH}$ fiber

8 phase, and the separation resolution was not affected by increasing the mobile phase

$9 \quad$ linear velocity.

10 Acrylics are a very versatile family of monomers. A large number of acrylic

11 monomers that contain different functional ligands is industrially available.

12 Implementation of a similar modification route would allow the functionalization of the 13 nylon 6 C-CP fibers with a variety of acrylic monomers such as (3-

14 acrylamidopropyl)trimethylammonium chloride for strong anion exchange, $\mathrm{N}$-[3-

15 (dimethylamino)propyl]acrylamide for weak anion exchange, 3-allyloxy-2-hydroxy-1-

16 propanesulfonic acid for strong cation exchange and allyl glycidyl ether for epoxide

17 coupling chemistry. Although more study of the modification conditions and the protein

18 separations on nylon C-CP fiber stationary phase is still needed, the results from this

19 study suggest that the nylon C-CP fiber modified by microwave-assisted grafting

20 polymerization has a great potential for protein separations on the analytical and

21 preparative scales.

22

23 Acknowledgements 
This study was supported by the National Science Foundation Division of

2 Chemistry [Grant number CHE-1307078].The authors appreciate the help from Dr. Qian

3 Haijun (Clemson University Electron Microscope Facility) on SEM instrumentation and

4 Ms. Kim Ivey (Analytical Testing Lab, Materials Science \& Engineering, Clemson

5 University) on ATR-FTIR instrumentation. The authors declare no financial conflicts of

6 interest. 


\section{References}

4 [1] S. Fekete, D. Guillarme, Ultra-high-performance liquid chromatography for the

5 characterization of therapeutic proteins, TrAC-Trends Anal. Chem., 63 (2014) 76-84.

6 [2] U. Gottschalk, Downstream processing of monoclonal antibodies: from high dilution

7 to high purity, Biopharm. Int., 18 (2005) 42-58.

8 [3] F.M. Wurm, Production of recombinant protein therapeutics in cultivated mammalian

9 cells, Nat. Biotechnol., 22 (2004) 1393-1398.

10 [4] P. Gronemeyer, R. Ditz, J. Strube, Trends in Upstream and Downstream Process

11 Development for Antibody Manufacturing, Bioeng., 1 (2014) 188-212.

12 [5] U. Gottschalk, Bioseparation in Antibody Manufacturing: The Good, The Bad and 13 The Ugly, Biotechnol. Progr., 24 (2008) 496-503.

14 [6] J. Thömmes, M. Etzel, Alternatives to Chromatographic Separations, Biotechnol. 15 Prog., 23 (2007) 42-45.

16 [7] M.R. Ladisch, Bioseparations Engineering: Principles, Practice, and Economics, 17 Wiley-Interscience, New York, 2001.

18 [8] G. Carta, A. Jungbauer, Protein Chromatography: Process Development and Scale19 Up, Wiley-VCH, Weinheim, 2010.

20 [9] U.D. Neue, HPLC Columns: Theory, Technology, and Practice, Wiley-VCH, New 21 York, 1997.

22 [10] T.H. Walter, R.W. Andrews, Recent innovations in UHPLC columns and 23 instrumentation, TrAC-Trends Anal. Chem., 63 (2014) 14-20. 
1 [11] S. Fekete, J. Schappler, J.-L. Veuthey, D. Guillarme, Current and future trends in

$2 \quad$ UHPLC, TrAC-Trends Anal. Chem., 63 (2014) 2-13.

3 [12] J.J. Kirkland, F.A. Truszkowski, C.H. Dilks, G.S. Engel, Superficially porous silica

4 microspheres for fast high-performance liquid chromatography of macromolecules, J.

5 Chromatogr. A, 890 (2000) 3-13.

6 [13] S.A. Schuster, B.M. Wagner, B.E. Boyes, J.J. Kirkland, Optimized superficially

7 porous particles for protein separations, J. Chromatogr. A, 1315 (2013) 118-126.

8 [14] F. Svec, J.M.J. Frechet, Continuous rods of macroporous polymer as high-

9 performance liquid chromatography separation media, Anal. Chem., 64 (1992) 820-822.

10 [15] R. Ghosh, Protein separation using membrane chromatography: opportunities and 11 challenges, J. Chromatogr. A, 952 (2002) 13-27.

12 [16] R.K. Marcus, Use of polymer fiber stationary phases for liquid chromatography

13 separations: Part I--Physical and chemical rationale, Journal of separation science, 31

$14 \quad(2008)$ 1923-1935.

15 [17] R.D. Arrua, M. Talebi, T.J. Causon, E.F. Hilder, Review of recent advances in the 16 preparation of organic polymer monoliths for liquid chromatography of large molecules, 17 Anal. Chim. Acta, 738 (2012) 1-12.

18 [18] N. Tanaka, D.V. McCalley, Core-Shell, Ultrasmall Particles, Monoliths, and Other 19 Suport Materials in High Performance Liquid Chromatography, Anal. Chem., 88 (2016) $20 \quad 279-298$.

21 [19] M. Ladisch, L. Zhang, Fiber-based monolithic columns for liquid chromatography, 22 Analytical and bioanalytical chemistry, 408 (2016) 6871-6883. 
1 [20] R.K. Marcus, W.C. Davis, B.C. Knippel, L. LaMotte, T.A. Hill, D. Perahia, J.D.

2 Jenkins, Capillary-channeled polymer fibers as stationary phases in liquid

3 chromatography separations, J. Chromatogr. A, 986 (2003) 17-31.

4 [21] D.M. Nelson, R.K. Marcus, Characterization of Capillary-Channeled Polymer Fiber

5 Stationary Phases for High-Performance Liquid Chromatography Protein Separations:

6 Comparative Analysis with a Packed-Bed Column, Anal. Chem., 78 (2006) 8462-8471.

7 [22] K.M. Randunu, R.K. Marcus, Microbore polypropylene capillary channeled polymer

8 (C-CP) fiber columns for rapid reversed-phase HPLC of proteins, Analytical and

9 bioanalytical chemistry, 404 (2012) 721-729.

10 [23] K.M. Randunu, R.K. Marcus, Initial Evaluation of Protein Throughput and Yield

11 Characteristics on Nylon 6 Capillary-Channeled Polymer (C-CP) Fiber Stationary

12 Phases by Frontal Analysis, Biotechnol. Prog., 29 (2013) 1222-1229.

13 [24] Z. Wang, R.K. Marcus, Roles of Interstitial Fraction and Load Linear Velocity on the 14 Dynamic Biding Capacity of Proteins on Capillary Channeled Polymer Fiber Columns, 15 Biotechnol. Progr., 15 (2015) 97-109.

16 [25] A.J. Schadock-Hewitt, R.K. Marcus, Initial evaluation of protein A modified capillary-

17 channeled polymer fibers for the capture and recovery of immunoglobulin G, Journal of 18 separation science, 37 (2014) 495-504.

19 [26] Z. Wang, R.K. Marcus, Determination of Pore Size Distributions in Capillary20 Channeled Polymer Fiber Stationary Phases by Inverse Size Exclusion 21 Chromatography (iSEC) and Implications for Fast Protein Separations, J. Chromatogr. 22 A, 1351 (2014) 82-89. 
1 [27] R.D. Stanelle, M. Mignanelli, P. Brown, R.K. Marcus, Capillary-channeled polymer

2 (C-CP) fibers as a stationary phase in microbore high-performance liquid

3 chromatography columns, Analytical and bioanalytical chemistry, 384 (2006) 250-258.

4 [28] J.M. Randunu, S. Dimartino, R.K. Marcus, Dynamic Evaluation of Polypropylene

5 Capillary-Channeled Fibers as a Stationary Phase in High Performance Liquid

6 Chromatography, Journal of separation science, 35 (2012) 3270-3280.

7 [29] R. Stanelle, R.K. Marcus, Nylon-6 capillary-channeled polymer (C-CP) fibers as a

8 hydrophobic interaction chromatography stationary phase for the separation of proteins,

9 Analytical and bioanalytical chemistry, 393 (2009) 273-281.

10 [30] R.D. Stanelle, C.M. Straut, R.K. Marcus, Nylon-6 Capillary-Channeled Polymer

11 Fibers as a Stationary Phase for the Mixed-Mode lon Exchange/Reversed-Phase

12 Chromatography Separation of Proteins, J. Chromatogr. Sci., 45 (2007) 415-421.

13 [31] T.K.F. Chambers, James., Effect of polystyrene-divinylbenzene resin sulfonation on

14 solute retention in high-performance liquid chromatography, J. Chromatogr. A, (1998)

$15 \quad 139-147$.

16 [32] Y.-b.H. Yang, Kervin.Kindsvater, John., Characterization of a novel stationary

17 phase dervived from a hydrophilic polystyrene-based resin for protein cation-exchange

18 high-performance liquid chromatography, J. Chromatogr. A, 723 (1996) 1-10.

19 [33] L. Jiang, R.K. Marcus, Biotin-functionalized poly(ethylene terephthalate) capillary-

20 channeled polymer fibers as HPLC stationary phase for affinity chromatography, Anal

21 Bioanal Chem, 407 (2015) 939-951. 
2 terephthalate) capillary channeled-polymer fibers for anion exchange chromatography

3 of proteins, J. Chromatogr. A, 1410 (2015) 200-209.

4 [35] L. Jiang, R.K. Marcus, Comparison of analytical protein separation characteristics

5 for three amine-based capillary-channeled polymer (C-CP) stationary phases, Analytical

6 and bioanalytical chemistry, (2015) 1-11.

7 [36] L. Jiang, A.J. Schadock-Hewitt, L.X. Zhang, R.K. Marcus, Evaluation of synthesized

8 lipid tethered ligands for surface functionalization of polypropylene capillary-channeled

9 polymer fiber stationary phases, Analyst, 140 (2015) 1523-1534.

10 [37] A.J. Schadock-Hewitt, J.J. Pittman, K.A. Christensen, R.K. Marcus, Head group-

11 functionalized poly(ethyleneglycol)-lipid (PEG-lipid) surface modification for highly

12 selective analyte extractions on capillary-channeled polymer (C-CP) fibers, Analyst, 139 $13 \quad$ (2014) 2108-2113.

14 [38] P. DePhillips, A.M. Lenhoff, Determinants of protein retention characteristics on 15 cation-exchange adsorbents, J. Chromatogr. A, 933 (2001) 57-72.

16 [39] B. Gu, Y. Li, M.L. Lee, Polymer Monoliths with Low Hydrophobicity for Strong 17 Cation-Exchange Capillary Liquid Chromatography of Peptides and Proteins, Anal. 18 Chem., 79 (2007) 5848-5855.

19 [40] A.K. Hunter, G. Carta, Protein adsorption on novel acrylomio-based polymeric ion 20 exhangers II. Adsorption rates and column behavior, J. Chromatogr. A, 897 (2000) 81 2197.

22 [41] A.J. Schadock-Hewitt, J.J. Pittman, K.A. Stevens, R.K. Marcus, Comparison of Two 23 Types of Nylon 6 Capillary-Channeled Polymer (C-CP) Fiber Stationary Phases 
1 Towards the Separation of Proteins via Ion Exchange Chromatography, J. Appl. Polym.

2 Sci., 128 (2013) 1257-1265.

3 [42] Q. Zhao, X. Gu, S. Zhang, M. Dong, P. Jiang, Z. Hu, Surface modification of

4 polyamide 66 fabric by microwave induced grafting with 2-hydroxyethyl methacrylate,

5 Surf. Coat. Technol., 240 (2014) 197-203.

6 [43] H.K. Trang, A.J. Schadock-Hewitt, L. Jiang, R.K. Marcus, Evaluation of loading

7 characteristics and lgG binding performance of Staphylococcal Protein A on

8 polypropylene capillary-channeled polymer fibers, J. Chromatogr. B, 1015 (2016) 92-

9104.

10 [44] F.J. Xu, J.P. Zhao, E.T. Kang, K.G. Neoh, J. Li, Functionalization of Nylon

11 Membranes via Surface-Initiated Atom-Transfer Radical Polymerization, Langmuir, 23

12 (2007) 8585-8592.

13 [45] M. Herrera-Alonso, T.J. McCarthy, X. Jia, Nylon Surface Modification: 2. Nylon-

14 Supported Composite Films, Langmuir, 22 (2006) 1646-1651.

15 [46] J. Deng, L. Wang, L. Liu, W. Yang, Developments and new applications of UV-

16 induced surface graft polymerizations, Prog. Polym. Sci., 34 (2009) 156-193.

17 [47] H.-S. Choi, Y.-S. Kim, Y. Zhang, S. Tang, S.-W. Myung, B.-C. Shin, Plasma-

18 induced graft co-polymerization of acrylic acid onto the polyurethane surface, Surf. Coat.

19 Technol., 182 (2004) 55-64.

20 [48] A. Bhattacharya, B.N. Misra, Grafting: a versatile means to modify polymers:

21 Techniques, factors and applications, Prog. Polym. Sci., 29 (2004) 767-814. 
1 [49] C. Zhang, L. Liao, S. Gong, Recent developments in microwave-assisted

2 polymerization with a focus on ring-opening polymerization, Green Chem., 9 (2007)

$3 \quad 303-314$.

4 [50] S. Sinnwell, H. Ritter, Recent advances in microwave-assisted polymer synthesis,

5 Aust. J. Chem., 60 (2007) 729-743.

6 [51] R. Hoogenboom, U.S. Schubert, Microwave-assisted polymer synthesis: recent

7 developments in a rapidly expanding field of research, Macromol. Rapid Commun., 28

$8 \quad$ (2007) 368-386.

9 [52] F. Wiesbrock, R. Hoogenboom, U.S. Schubert, Microwave-assisted polymer

10 synthesis: state-of-the-art and future perspectives, Macromol. Rapid Commun., 25 11 (2004) 1739-1764.

12 [53] C.O. Kappe, B. Pieber, D. Dallinger, Microwave effects in organic synthesis: Myth 13 or Reality?, Angew. Chem. Int. Ed., 52 (2013) 1088-1094.

14 [54] G.B. Dudley, A.E. Stiegman, M.R. Rosana, Correspondence on microwave effects 15 in organic synthesis, Angew. Chem. Int. Ed., 52 (2013) 7918-7923.

16 [55] A. Sosnik, G. Gotelli, G.A. Abraham, Microwave-assisted polymer synthesis (MAPS)

17 as a tool in biomaterials science: How new and how powerful, Prog. Polym. Sci., 36 $18 \quad(2011) 1050-1078$.

19 [56] D. Hunkeler, Mechanism and kinetics of the persulfate-initiated polymerization of 20 acrylamide, Macromolecules, 24 (1991) 2160-2171.

21 [57] E. Rusu, G. Rusu, D.-O. Dorohoi, Influence of temperature on structures of 22 polymers with $\varepsilon$-caprolactam units studied by FT-IR spectroscopy, Polimery, 54 (2009) $23 \quad 347-353$. 
1 [58] L.J. Kirwan, P.D. Fawell, W. van Bronswijk, In Situ FTIR-ATR Examination of

2 Poly(acrylic acid) Adsorbed onto Hematite at Low pH, Langmuir, 19 (2003) 5802-5807.

3 [59] B. Gong, C. Ke, X. Geng, Preparation of weak cation exchange packings based on

4 monodisperse poly(glycidyl methacrylate-co-ethylene dimethacrylate) beads and their

5 chromatographic properties, Analytical and bioanalytical chemistry, 375 (2003) 769-774.

6 [60] Y. Wei, X. Huang, R. Liu, Y. Shen, X. Geng, Preparation of a monolithic column for

7 weak cation exchange chromatography and its application in the separation of

8 biopolymers, Journal of separation science, 29 (2006) 5-13.

9 [61] K.L. Zhao, C. Song, F. Wang, Q. Bai, "Click chemistry" preparation of WCX

10 packings for protein separation, Chinese Chemical Letters, 23 (2012) 305-308.

11 [62] I.N. Savina, I.Y. Galaev, B. Mattiasson, lon-exchange macroporous hydrophilic gel

12 monolith with grafted polymer brushes, Journal of Molecular Recognition, 19 (2006)

$13 \quad 313-321$.

14 [63] Z. Chen, L. Xu, Y. Liang, J. Wang, M. Zhao, Y. Li, Polyethylene glycol diacrylate-

15 based supermacroporous monolithic cryogel as high-performance liquid

16 chromatography stationary phase for protein and polymeric nanoparticle separation,

17 Journal of Chromatography A, 1182 (2008) 128-131. 


\section{Figure captions}

3 Figure 1. ATR-FTIR spectrum of the native and modified nylon C-CP fibers.

4 Figure 2. SEM images of the (left) native nylon C-CP fiber and (right) nylon-COOH C-

5 CP fiber and column cross-sections.

6 Figure 3. Lysozyme loading breakthrough curves on the nylon-COOH C-CP fiber

7 column at constant mobile phase linear velocity and various protein loading

8 concentrations. The breakthrough curves are plotted on the time basis. (Column length:

9200 mm, I.D.: 0.762 mm. Loading buffer: lysozyme in 20 mM phosphate buffer, pH 6.5.

10 Flow rate: $0.4 \mathrm{~mL} \mathrm{~min}^{-1}$. Detection: $280 \mathrm{~nm}$ )

11 Figure 4. Lysozyme loading breakthrough curves on the nylon-COOH C-CP fiber

12 column at constant protein loading concentration and various mobile phase linear

13 velocities. The breakthrough curves are plotted on the volume basis. (Column length:

$14200 \mathrm{~mm}$, I.D.: $0.762 \mathrm{~mm}$. Loading buffer: $1 \mathrm{mg} \mathrm{mL}^{-1}$ lysozyme in $20 \mathrm{mM}$ phosphate

15 buffer, $\mathrm{pH}$ 6.5. Detection: $280 \mathrm{~nm}$ )

16 Figure 5. Chromatograms of 10 continuous lysozyme loading/elution cycles on the 17 nylon-COOH C-CP fiber column without column regeneration in between. (Column 18 length: $200 \mathrm{~mm}$, I.D.: $0.762 \mathrm{~mm} .1 \mathrm{mg} \mathrm{mL}^{-1}$ of lysozyme in buffer $A$ was loaded at 0.5 $19 \mathrm{~mL} \mathrm{~min}^{-1}$ for $8 \mathrm{~min}$ at room temperature $\left(\sim 20^{\circ} \mathrm{C}\right)$, column washed with buffer $\mathrm{A}$ at 0.5 $20 \mathrm{~mL} \mathrm{~min}^{-1}$ for $15 \mathrm{~min}$, and elution with buffer $\mathrm{B}$ at $0.5 \mathrm{~mL} \mathrm{~min}^{-1}$ for $7 \mathrm{~min}$. Detection: 280 $21 \mathrm{~nm}$. 
1 Figure 6. Chromatograms of lysozyme loading/elution on 5 nylon-COOH C-CP fiber

2 columns prepared in different weeks. (Column length: $200 \mathrm{~mm}$, I.D.: $0.762 \mathrm{~mm} .1 \mathrm{mg}$

$3 \mathrm{~mL}^{-1}$ of lysozyme in buffer $A$ was load at $0.5 \mathrm{~mL} \mathrm{~min}^{-1}$ for $8 \mathrm{~min}$ at room temperature (

$420^{\circ} \mathrm{C}$ ), columns washed with buffer $\mathrm{A}$ at $0.5 \mathrm{~mL} \mathrm{~min}^{-1}$ for $15 \mathrm{~min}$, and elution with buffer

$5 \quad$ B at $0.5 \mathrm{~mL} \min ^{-1}$ for $7 \mathrm{~min}$. Detection: $280 \mathrm{~nm}$.)

6 Figure 7. Separations of (1) myoglobin, (2) a-chymotrypsinogen A, (3) cytochrome C

7 and (4) lysozyme on the native and nylon- $\mathrm{COOH} \mathrm{C-CP} \mathrm{fiber} \mathrm{columns} \mathrm{at} \mathrm{linear} \mathrm{velocities}$

8 of 44 and $219 \mathrm{~cm} \mathrm{~min}^{-1}\left(0.1\right.$ and $\left.0.5 \mathrm{~mL} \mathrm{~min}^{-1}\right)$ reported on a volume basis. Blue

9 dashed lines depict the gradient composition of buffer B used in the separation.

10 (Injection volume: $5 \mu \mathrm{L}$, sample concentration: $0.25 \mathrm{mg} \mathrm{mL}^{-1}$ of each protein, 11 temperature: $\sim 20^{\circ} \mathrm{C}$, detection: $280 \mathrm{~nm}$ ) 
${ }^{\star}$ Graphical Abstract

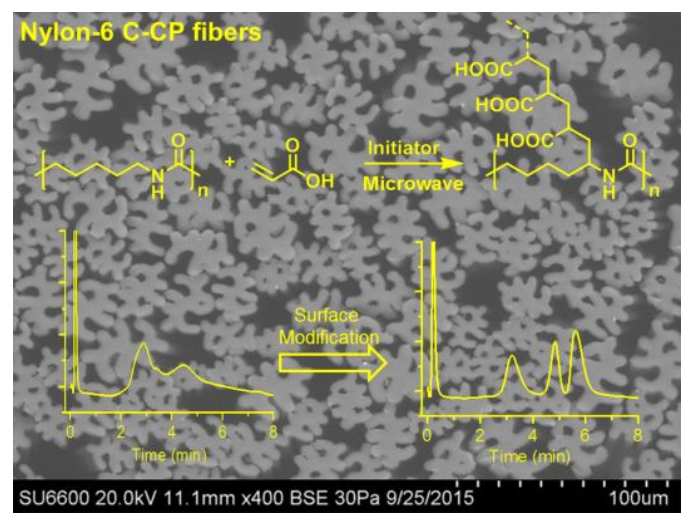


Table 1. Dynamic loading capacity (DLC) of lysozyme on nylon- $\mathrm{COOH}$ column at different protein loading concentrations.

\begin{tabular}{|c|c|c|c|c|c|c|}
\hline \multirow{2}{*}{$\begin{array}{l}\text { Loading } \\
\text { Concentration } \\
\left(\mathrm{mg} \mathrm{mL}^{-1}\right)\end{array}$} & \multirow{2}{*}{$\begin{array}{c}\text { Native nylon } \\
\text { DLC @50\% BT } \\
\left(\mathrm{mg} \mathrm{g}^{-1}\right)\end{array}$} & \multirow{2}{*}{$\begin{array}{c}\text { Native Nylon } \\
\text { DLC @50\% BT } \\
\left(\mathrm{mg} \mathrm{mL}^{-1}\right)\end{array}$} & \multirow{2}{*}{$\begin{array}{c}\text { Nylon-COOH } \\
\text { DLC @50\% BT } \\
\left(\mathrm{mg} \mathrm{g}^{-1}\right)\end{array}$} & \multicolumn{3}{|c|}{ Nylon-COOH DLC (mg mL $\left.\mathrm{mL}^{-1}\right)$} \\
\hline & & & & @10\% BT & @50\% BT & $\begin{array}{c}10 \% / 50 \% \\
\text { Ratio }\end{array}$ \\
\hline 0.05 & $0.63 \pm 0.44$ & $0.37 \pm 0.26$ & $19.1 \pm 0.2$ & $9.21 \pm 0.08$ & $10.7 \pm 0.1$ & 0.86 \\
\hline 0.1 & $1.81 \pm 0.02$ & $0.7 \pm 0.01$ & $20.1 \pm 0.02$ & $9.18 \pm 0.02$ & $11.2 \pm 0.01$ & 0.82 \\
\hline 0.2 & $0.87 \pm 0.19$ & $0.52 \pm 0.11$ & $20.6 \pm 0.01$ & $9.44 \pm 0.01$ & $11.4 \pm 0.01$ & 0.82 \\
\hline 0.4 & $0.81 \pm 0.27$ & $0.48 \pm 0.16$ & $21.1 \pm 0.4$ & $9.71 \pm 0.21$ & $11.7 \pm 0.2$ & 0.83 \\
\hline 0.6 & $1.24 \pm 0.47$ & $0.74 \pm 0.28$ & $22.2 \pm 0.03$ & $10.4 \pm 0.02$ & $12.4 \pm 0.02$ & 0.84 \\
\hline 0.8 & $0.94 \pm 0.67$ & $0.56 \pm 0.40$ & $22.3 \pm 0.04$ & $10.4 \pm 0.03$ & $12.4 \pm 0.02$ & 0.84 \\
\hline 1.0 & $1.66 \pm 0.10$ & $0.99 \pm 0.06$ & $22.6 \pm 0.9$ & $10.5 \pm 0.5$ & $12.6 \pm 0.5$ & 0.84 \\
\hline
\end{tabular}


Table 2 Comparison of nylon- $\mathrm{COOH}$ with other WCX phases

\begin{tabular}{|c|c|c|c|c|}
\hline Name & $\begin{array}{l}\text { Protein binding capacity } \\
\qquad\left(\mathrm{mg} \mathrm{mL}^{-1}\right)\end{array}$ & $\begin{array}{l}\text { Linear velocity } \\
\qquad\left(\mathrm{cm} \mathrm{min}{ }^{-1}\right)\end{array}$ & $\begin{array}{l}\text { Bed height } \\
\qquad(\mathrm{mm})\end{array}$ & Ref \\
\hline Nylon-COOH C-CP fibers & 12 & $44-440$ & 200 & \\
\hline $\begin{array}{l}\text { Polyacrylate-grafted polyacrylamide cryogel } \\
\text { monolith }\end{array}$ & 6 & $\mathrm{~N} / \mathrm{A}$ & & [62] \\
\hline $\begin{array}{l}\text { Methacrylic acid-polyethylene glycol diacrylate } \\
\text { monolith }\end{array}$ & 0.065 & $<19$ & 70 & [63] \\
\hline CIMac $^{T M}$ CM monlith & $9-11$ & $\begin{array}{l}\text { Recommended 1-10 } \\
\text { Maximum } 15\end{array}$ & 5 & $\mathrm{BIA}$ \\
\hline ProSwift WCX-1S monolith & 23 & $\begin{array}{l}\text { Recommended } 6.4-25.6 \\
\text { Maximum } 32\end{array}$ & 50 & Thermo \\
\hline Sartobind® $\mathrm{C}$ membrane & 21 & $\begin{array}{l}\text { Recommended } 2-6 \\
\text { Maximum } 233\end{array}$ & 4 & Sartorius \\
\hline
\end{tabular}




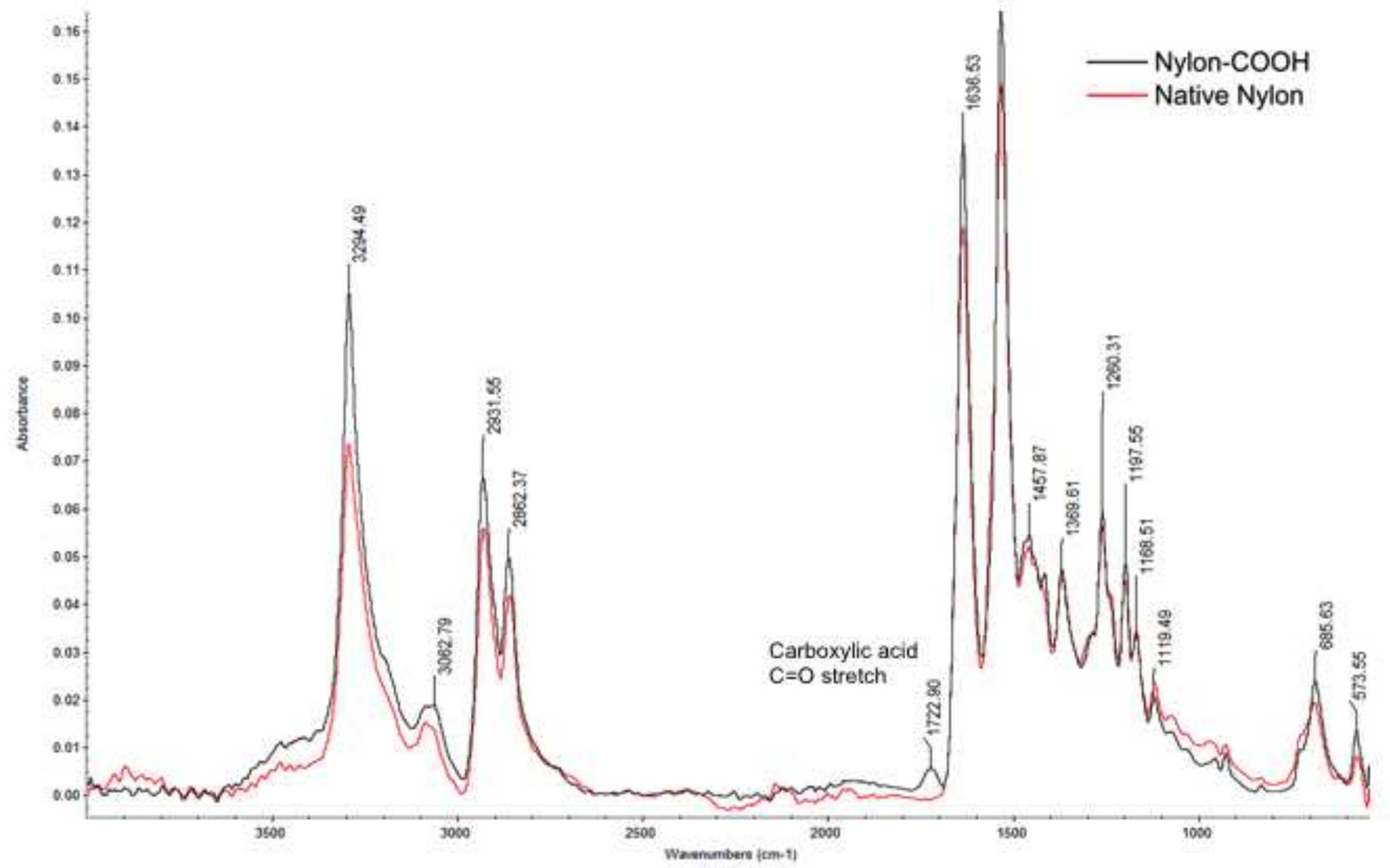

דִ̣ 


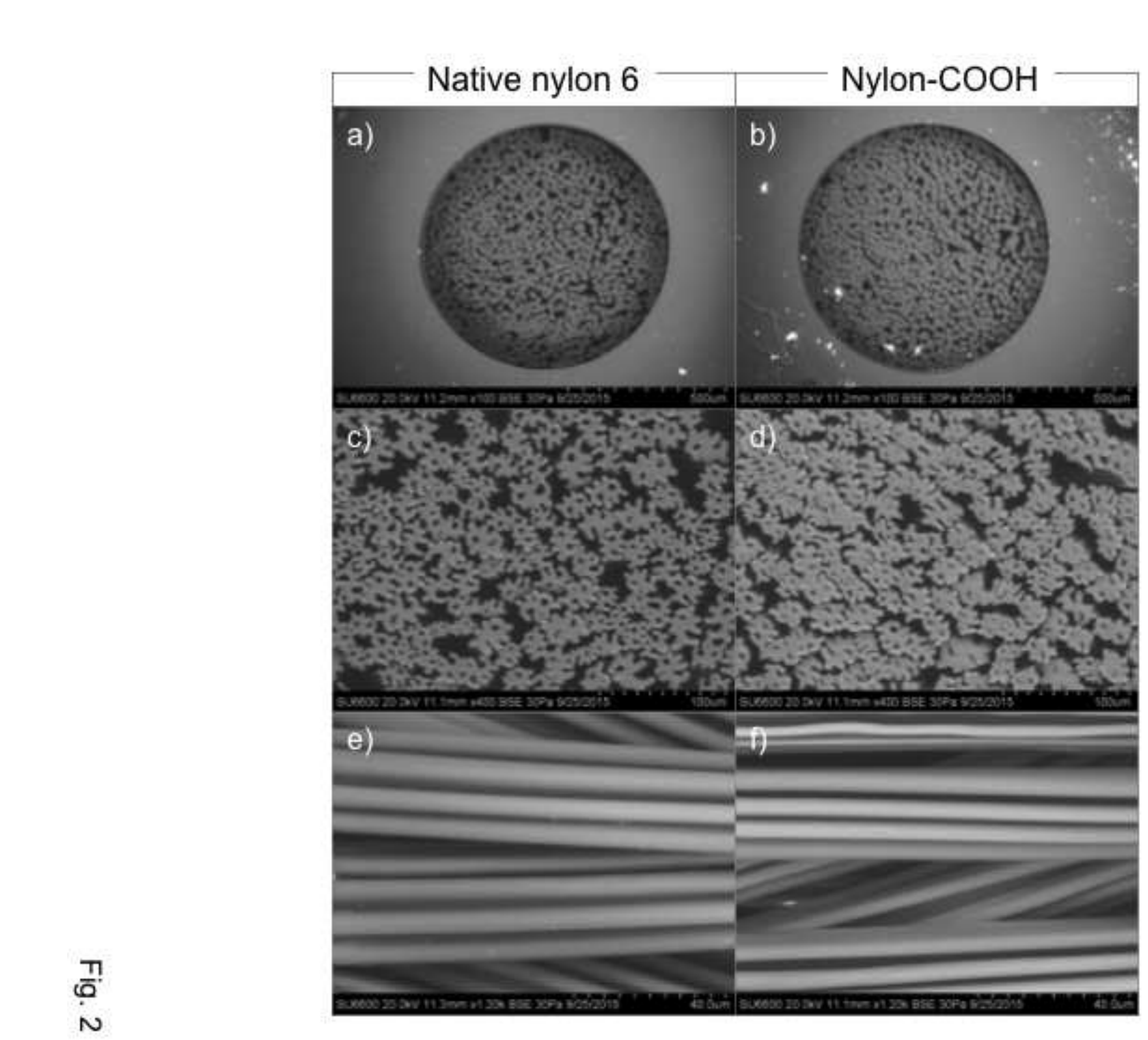

\section{Native nylon 6}

b) ,

e)

.

n




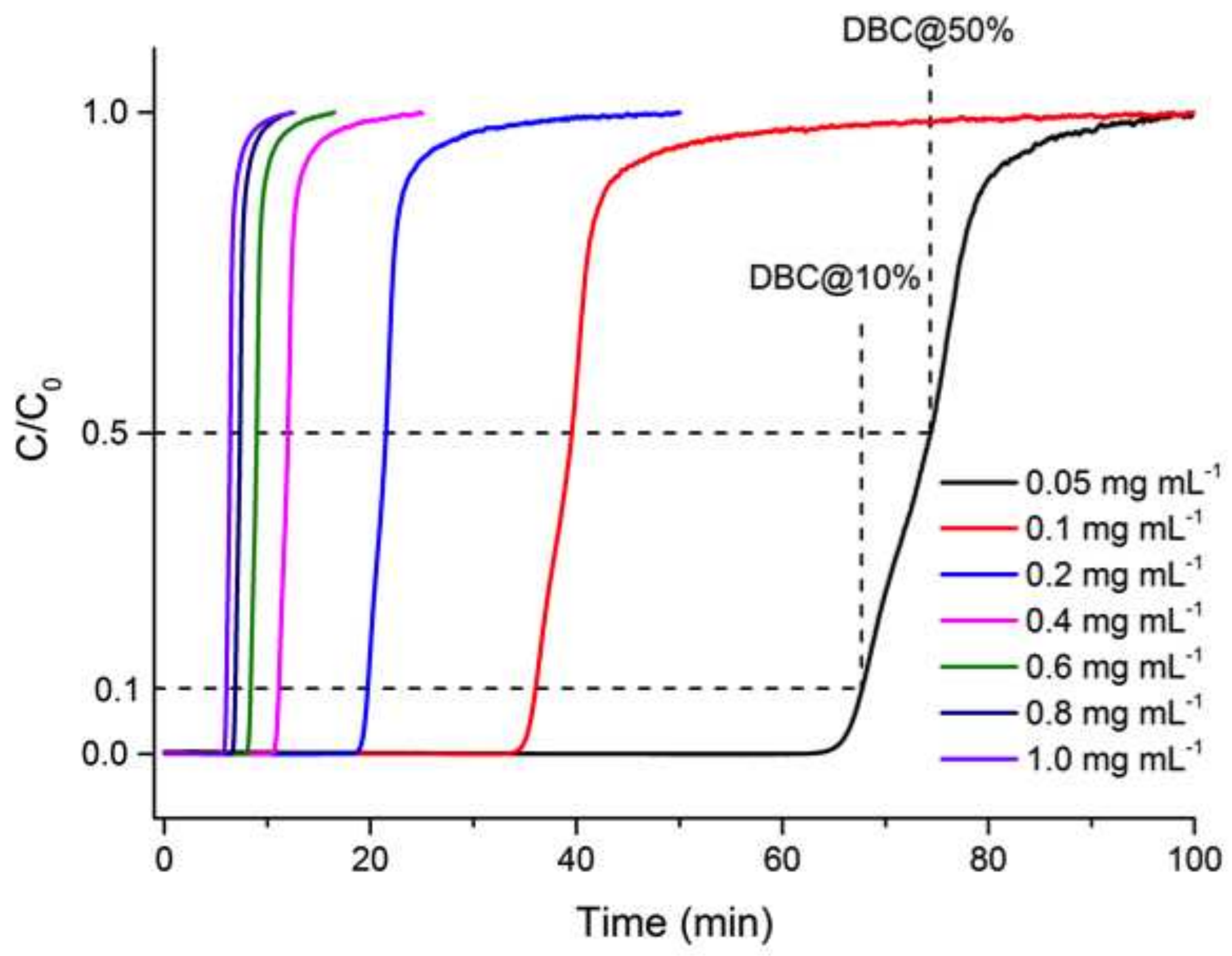

प़̣ 


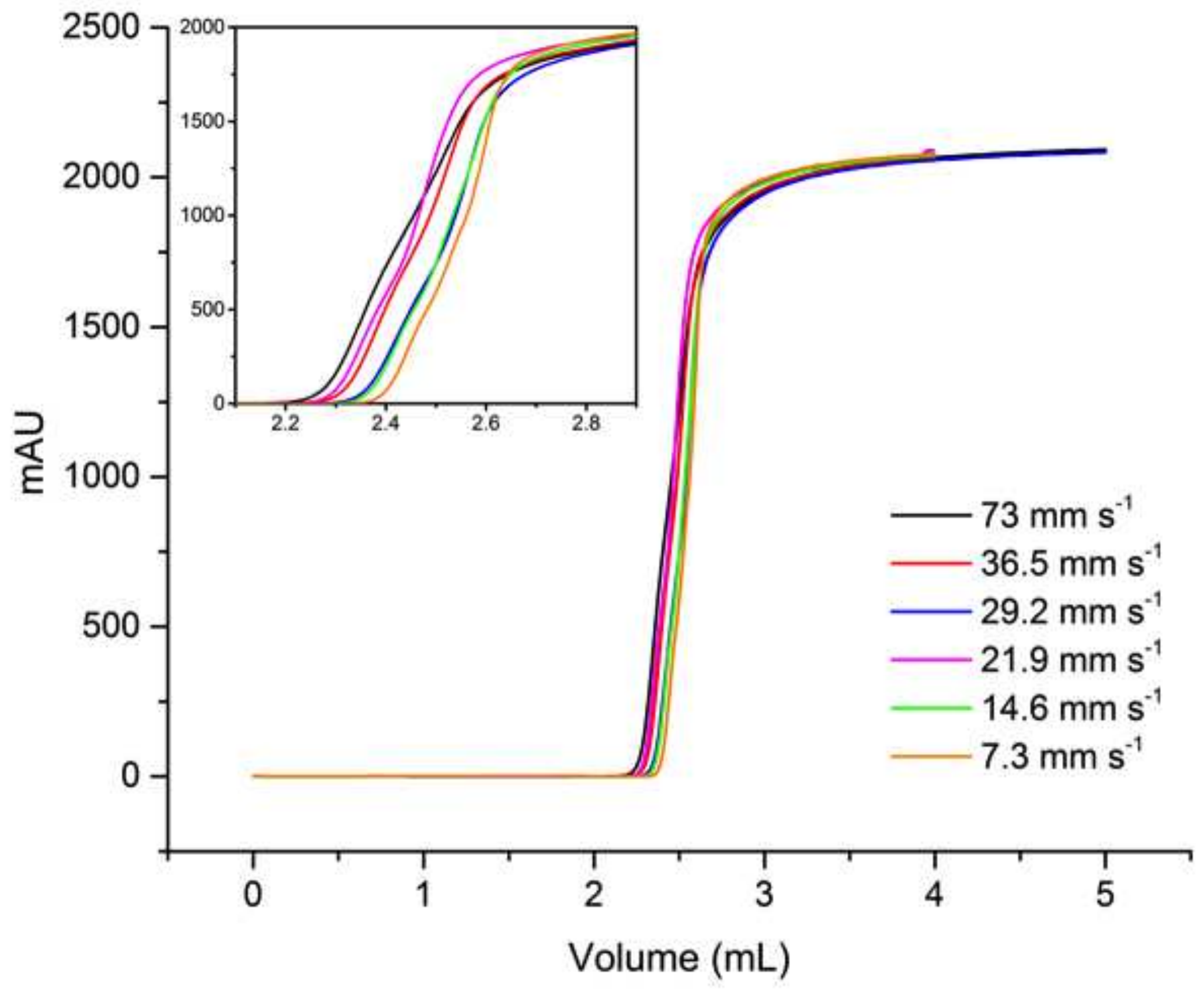

$T$
0
0 


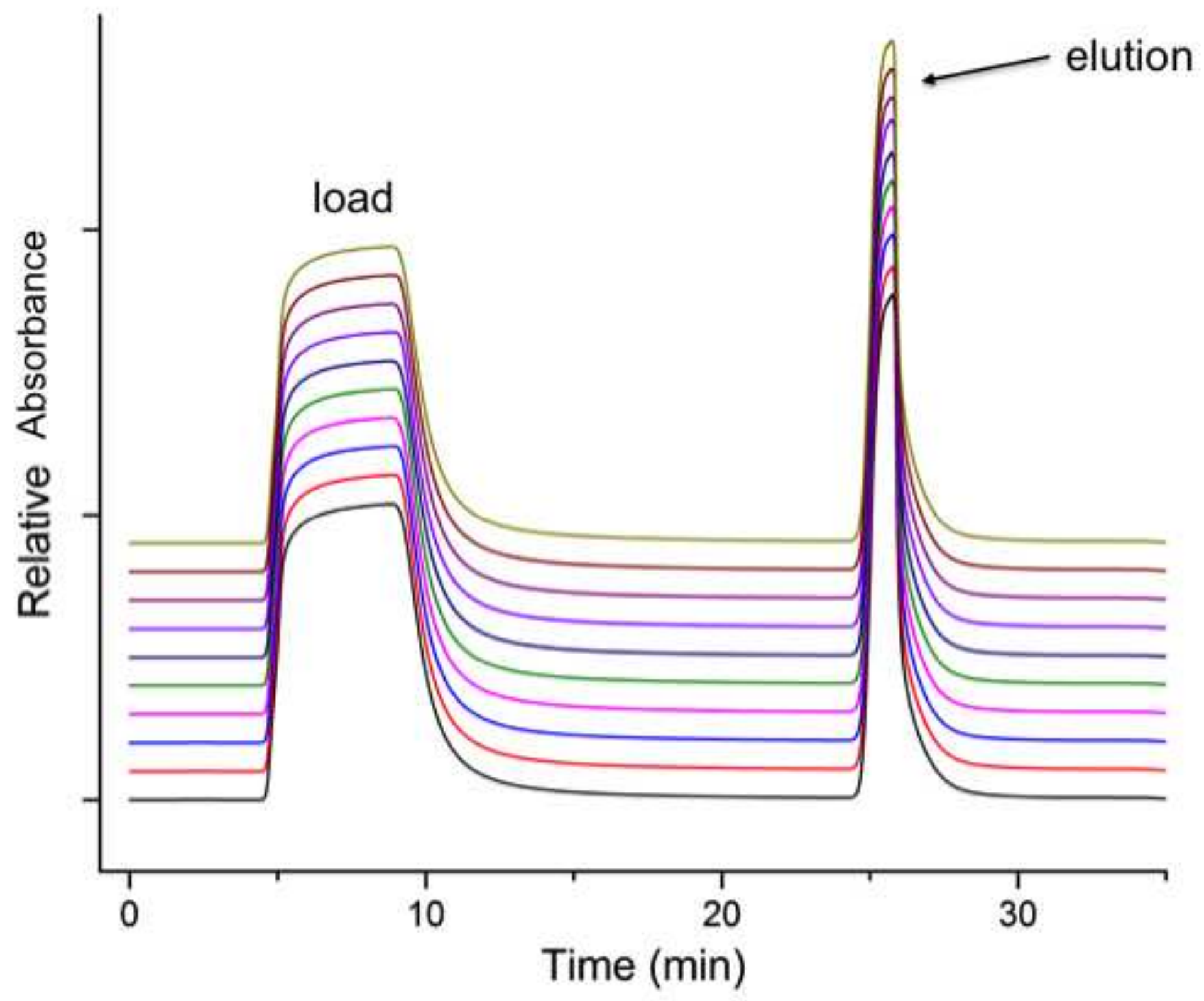

ํํ 


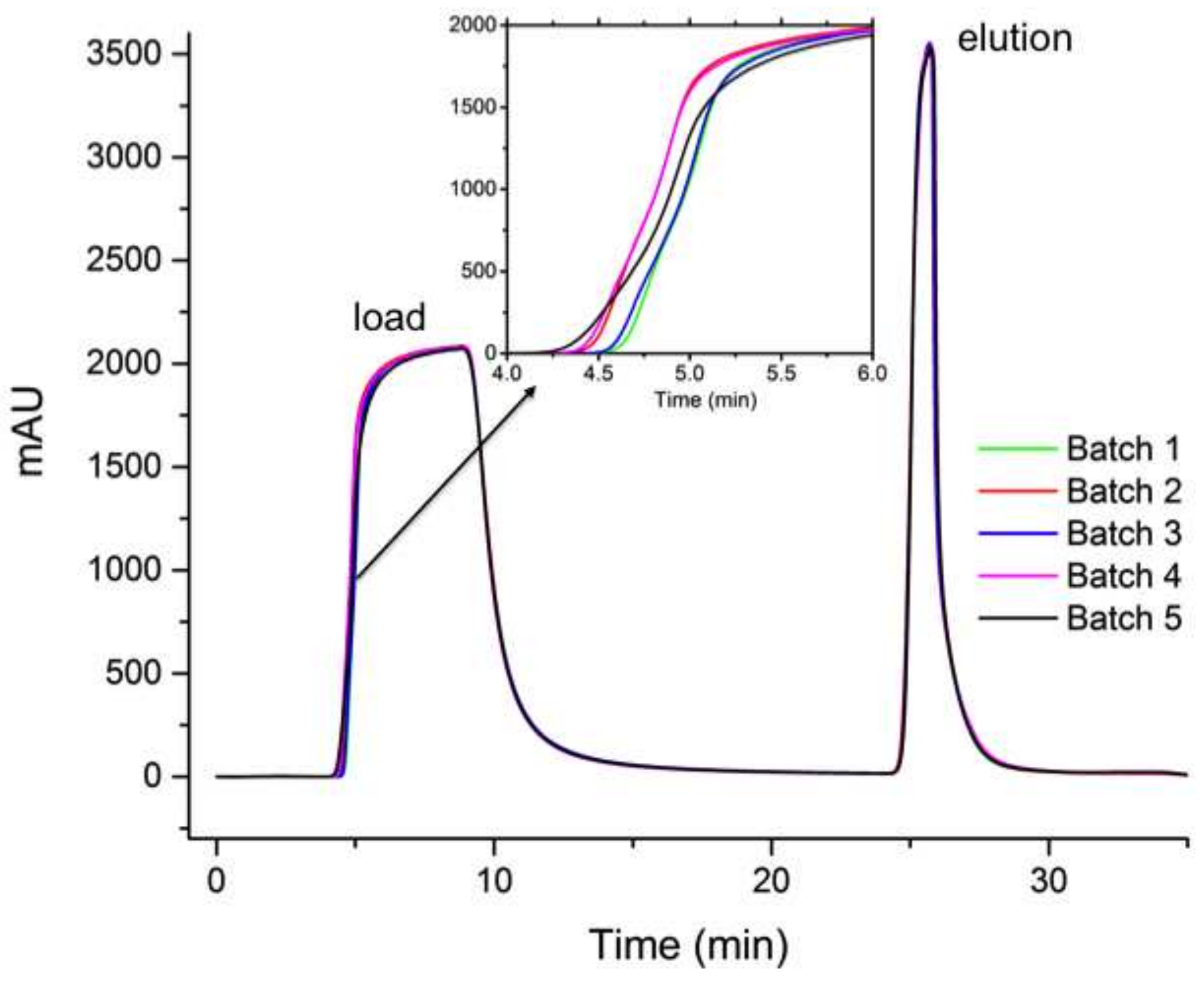

$\sigma$

Batch 1 Batch 2 atch 3 Batch 5 

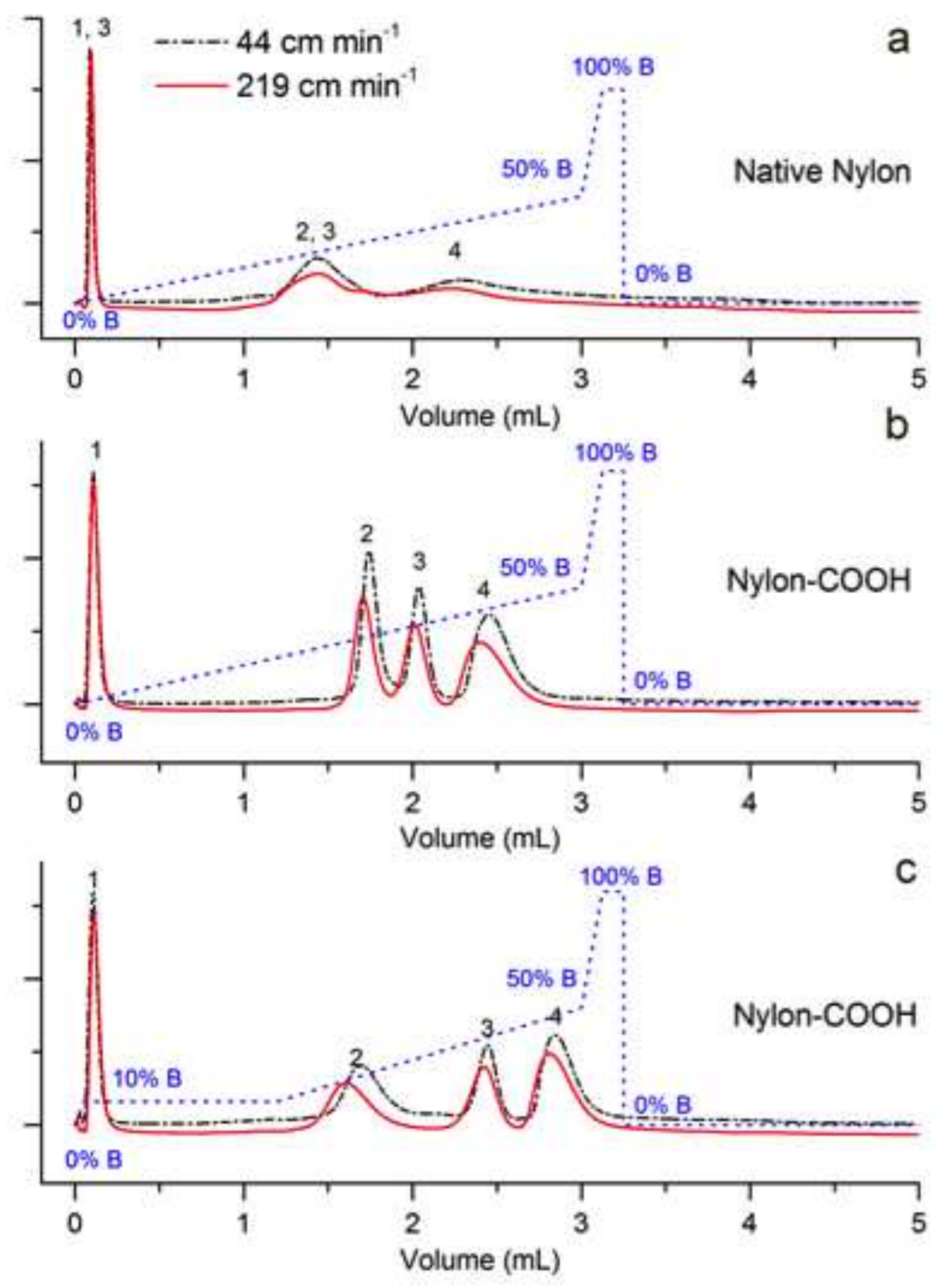